\title{
Characterization of the genes encoding the 3- carboxy-cis, cis-muconate-lactonizing enzymes from the 4-sulfocatechol degradative pathways of Hydrogenophaga intermedia S1 and Agrobacterium radiobacter S2
}

Correspondence

Andreas Stolz

Andreas.Stolz@

imb.Uni-Stuttgart.de

Received 15 May 2006

Revised 20 July 2006

Accepted 20 July 2006

\author{
Sad Halak, Tamara Basta,† Sibylle Bürger, Matthias Contzen $\ddagger$ \\ and Andreas Stolz
}

Institut für Mikrobiologie, Universität Stuttgart, Allmandring 31, D-70569 Stuttgart, Germany

\section{INTRODUCTION}

Aromatic compounds which carry sulfonic acid substituents directly attached to the aromatic ring system are extremely

tPresent address: Institut Pasteur, 25 Rue du Dr Roux, F-75015 Paris, France.

‡Present address: Chemisches und Veterinäruntersuchungsamt Stuttgart, Schaflandstr. 3/2, D-70736 Fellbach, Germany.

Abbreviations: CMLE, 3-carboxy-cis,cis-muconate-lactonizing enzyme; $\mathrm{NCBI}$, National Center for Biotechnology Information; P34OII, type 2 protocatechuate 3,4-dioxygenase.

The GenBank/EMBL/DDBJ accession numbers for the pcaB2S2 and pcaB2S1 sequences reported in this paper are AY769867 and AY769868, respectively. rare among natural compounds, but are produced in large quantities by the chemical industry as detergents, dispersants, dyes, optical brighteners, ion exchangers and pharmaceuticals (Tully, 1997). Laboratory studies have shown that a sulfonic acid substituent usually significantly decreases the rates of biodegradation, and several examples of the accumulation of sulfonated aromatics in the environment have been described (Alexander \& Lustigman, 1966; Alonso et al., 1999; Knepper, 2002; Riediker et al., 2000; Ruckstuhl et al., 2002; Wellens, 1990). The microbial degradation of aromatic sulfonic acids has mainly been studied using simple benzenesulfonates and naphthalenesulfonates as model compounds. These studies demonstrated that sulfonated substrates are in most cases initially desulfonated by the action of ring-hydroxylating dioxygenases to the corresponding diols (Brilon et al., 1981; 
Cook et al., 1999; Nörtemann et al., 1986; Ohe et al., 1990; Thurnheer et al., 1990; Wittich et al., 1988). In contrast, it has been found that 4 -aminobenzenesulfonate (sulfanilate) was initially deaminated by a co-culture of Hydrogenophaga intermedia S1 and Agrobacterium radiobacter S2 to 4sulfocatechol (Feigel \& Knackmuss, 1988). More recently, 4-sulfocatechol has also been described as an intermediate formed during the degradation of 1,3-benzenedisulfonate and linear alkylbenzenesulfonates (Contzen et al., 1996; Schulz et al., 2000; Dong et al., 2004; Schleheck et al., 2004). 4Sulfocatechol thus appears to be a central intermediate for the degradation of substituted sulfonated benzenes, which are released by humans in enormous quantities $\left(>10^{6}\right.$ tonnes annually) into the environment.

It was demonstrated for the sulfanilate-degrading mixed culture that 4-sulfocatechol was oxidized to 3-sulfomuconate by specifically adapted forms of protocatechuate 3,4dioxygenases. These 'type 2' enzymes were therefore distinguished from the classical protocatechuate 3,4dioxygenases ('type 1') which convert only protocatechuate (Feigel \& Knackmuss, 1993; Hammer et al., 1996). The genes encoding type 2 protocatechuate 3,4-dioxygenases (P34OIIs) have been cloned from $H$. intermedia S1 and A. radiobacter $\mathrm{S} 2$, and significant sequence similarities have been found among the genes encoding the type 1 and type 2 enzymes (Contzen \& Stolz, 2000; Contzen et al., 2001).

It has been suggested that 3-sulfomuconate is further converted in a cycloisomerization reaction to a sulfonated lactone (Fig. 1). This reaction is analogous to the cycloisomerization of 3-carboxy-cis,cis-muconate to 4-carboxymuconolactone found in the protocatechuate branch of the $\beta$-ketoadipate pathway, which is catalysed by 3-carboxycis,cis-muconate-lactonizing enzymes (CMLEs). The CMLE from Pseudomonas putida has been purified and the stereochemistry of the turnover of 3-carboxy-cis,cis-muconate has been analysed in some detail. In addition, the gene has been cloned and sequenced, and the crystal structure of the enzyme has been determined (Ornston, 1966; Williams et al., 1992; Yang et al., 2004).

In the present study, 3-sulfomuconate was prepared and the enzymes responsible for the metabolism of 3-sulfomuconate were characterized. The aim of the study was a further analysis of the enzymic and evolutionary relationship between the degradative pathways for protocatechuate and 4-sulfocatechol. The central questions in this context were if the 3 -sulfomuconate-converting enzymes were indeed derived from 3-carboxy-cis, cis-muconate-converting enzymes, and if indications for a specific adaptation of these enzymes for the conversion of sulfonated substrates could be found.

\section{METHODS}

Bacterial strains and media. The isolation and characterization of Hydrogenophaga intermedia S1 (DSMZ 5680) and Agrobacterium radiobacter S2 (DSMZ 5681) have been reported before (Contzen

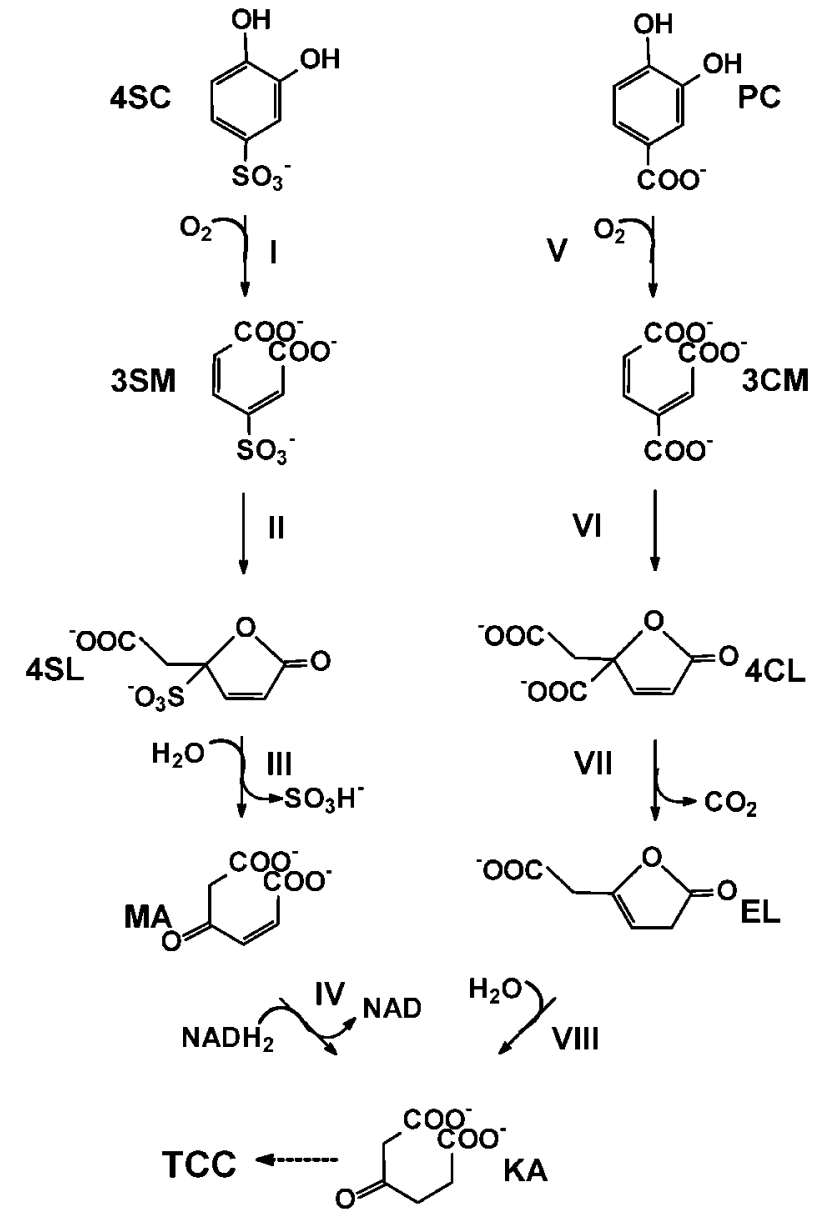

Fig. 1. Proposed pathway for the degradation of 4-sulfocatechol and protocatechuate by $A$. radiobacter S2 (Feigel \& Knackmuss, 1993). Key to enzymes: I, P34OII; II, CMLE type 2; III, sulfomuconolactone hydrolase; IV, maleylacetate reductase; $\mathrm{V}$, protocatechuate 3,4-dioxygenase type 1; VI, CMLE type $1 ;$ VII, $\gamma$-carboxymuconolactone decarboxylase; VIII, $\beta$ ketoadipate enol-lactone hydrolase. Key to compounds: 4SC, 4-sulfocatechol; 3SM, 3-sulfomuconate; 4SL, 4-sulfomuconolactone (4-carboxymethylene-4-sulfo-but-2-en-olide); MA, maleylacetate; KA, $\beta$-ketoadipate; $\mathrm{PC}$, protocatechuate; $3 \mathrm{CM}$, 3-carboxy-cis,cis-muconate; 4CL, carboxymuconolactone; EL, $\beta$-ketoadipate enol-lactone.

et al., 2000; Feigel \& Knackmuss, 1988, 1993). The strains were routinely cultivated separately in SHPG-medium as described elsewhere (Contzen et al., 2000; Feigel \& Knackmuss, 1988, 1993).

Pseudomonas putida PRS2000 (Hughes et al., 1988) was kindly provided by J. Gröning and M. Schlömann (TU Freiberg, Germany). The organism was grown at $30^{\circ} \mathrm{C}$ on a rotary shaker (100 r.p.m.) in a mineral medium according to Dorn et al. (1974) with protocatechuate $(7.5 \mathrm{mM})$ as sole source of carbon and energy. For isolation of genomic DNA, the strain was cultivated in liquid culture with $\mathrm{NB}[8 \mathrm{~g}$ dehydrated Nutrient Broth powder (Difco) and $5 \mathrm{~g} \mathrm{NaCl}^{-1}$ ].

Escherichia coli DH5 $\alpha$, JM 109, BL21(DE3)(pLysS) and BL21(DE3)(pLysS) Star (Invitrogen) were used as host strains for 
Table 1. Plasmids used in this study

\begin{tabular}{|c|c|c|}
\hline Plasmid & Relevant characteristics & Source or reference \\
\hline pAC28 & Expression plasmid with the $\mathrm{T} 7$ promoter & Kholod \& Mustelin (2001) \\
\hline pMCS2-2 & $\begin{array}{l}\text { pcaG2, genes for a putative TRAP transport system, putative IclR regulator } \\
\text { and pcaB2S2 from A. radiobacter } \mathrm{S} 2 \text { in pBluescript II SK(+) }\end{array}$ & Contzen \& Stolz (2000) \\
\hline pSHCMC2S2 & $\begin{array}{l}\text { pcaB2S2 from A. radiobacter S2 in pAC28 (encodes ArCMLE2 with an amino-terminal } \\
\text { His-tag) }\end{array}$ & This study \\
\hline pSBCMC2S1 & pcaB2S1 from $H$. intermedia S1 in pJOE3075 & This study \\
\hline pSHCMC2S1 & $\begin{array}{l}\text { pcaB2S1 from } H \text {. intermedia S1 in pAC28 (encodes HiCMLE2 with an amino-terminal } \\
\text { His-tag) }\end{array}$ & This study \\
\hline pSHPpCMLE & pcaB from $P$. putida PRS2000 in pAC28 & This study \\
\hline
\end{tabular}

recombinant DNA work. E. coli strains were routinely cultured in Luria-Bertani (LB) medium supplied with ampicillin $\left(100 \mu \mathrm{g} \mathrm{ml}^{-1}\right)$ or kanamycin $\left(50 \mu \mathrm{g} \mathrm{ml}^{-1}\right)$, if appropriate.

E. coli BL21(DE3)(pLysS)(pETS2-X-II) (Contzen \& Stolz, 2000) was used for the synthesis of 3-carboxy-cis,cis-muconate and 3-sulfomuconate from protocatechuate and 4-sulfocatechol, respectively.

Plasmids and DNA manipulation techniques. Plasmid pBluescript II SK(+) was used for standard cloning experiments (Alting-Mees et al., 1992). The plasmid vectors pJOE3075 and pAC28 were used for high levels of gene expression (Kholod \& Mustelin, 2001; Stumpp et al., 2000). The characteristics of all plasmids used are given in Table 1.

The genomic DNA of H. intermedia S1 was prepared after SDS lysis and phenol extraction as described by Eulberg et al. (1997). The genomic
DNA from A. radiobacter $\mathrm{S} 2$ was extracted using a DNeasy Tissue Kit (Qiagen) and the genomic DNA of P. putida using an E.Z.N.A Bacterial DNA Kit (Peqlab Biotechnologie). Plasmid DNA from E. coli DH5 $\alpha$ was isolated with a GFX Micro Plasmid Prep kit (Pharmacia). Digestion of DNA with restriction endonucleases (MBI Fermentas), electrophoresis and ligation with T4 DNA ligase (MBI Fermentas) were performed according to standard procedures (Sambrook et al., 1989). Transformation of E. coli was done by the method of Chung et al. (1989). For cloning of certain PCR products a T-vector was prepared as described by Marchuk et al. (1991).

PCR. Oligonucleotides were custom-synthesized (Eurogentec) according to known or deduced sequences from various CMLEs (Table 2). PCR mixtures $(50 \mu \mathrm{l})$ for the amplification of genomic DNA contained $50 \mathrm{pmol}$ each primer, $0 \cdot 1-0 \cdot 2 \mu \mathrm{g}$ genomic DNA, $0.2 \mathrm{mM}$ each deoxynucleotide triphosphate, Taq DNA polymerase $(2-2 \cdot 5 \mathrm{U})$ and the corresponding reaction buffer (Eppendorf).

Table 2. Oligonucleotide primers used in this study

\begin{tabular}{|c|c|c|c|}
\hline Position & Primer name & $\begin{array}{c}\text { Amino acid } \\
\text { sequence (if relevant) }\end{array}$ & Deduced primer sequence $\left(5^{\prime} \rightarrow 3^{\prime}\right)^{\star}$ \\
\hline $\begin{array}{l}\text { Downstream of pcaG2 } \\
\text { in A. radiobacter } \mathrm{S} 2\end{array}$ & S1-pcaG/se & & CAAGCTACGTTGATCGTTACTGG \\
\hline Consensus in CMLEs $\dagger$ & c-S1-se/c & EAALARA $(\mathrm{Q} / \mathrm{E}) \mathrm{A}$ & GAYGCNGCNCTNGCNCGNGCNSAYGC \\
\hline Consensus in CMLEs $\dagger$ & c-S1-as/a & MPHKRNPV & ATGCCWCARAAGAGYAARCCNGTD \\
\hline $\begin{array}{l}\text { Inverse PCR with genomic DNA } \\
\text { of strain S1 }\end{array}$ & pcaBS1_1930F & & GTTGTCATCCACTGAGGTAGG \\
\hline $\begin{array}{l}\text { Inverse PCR with genomic DNA } \\
\text { of strain S1 }\end{array}$ & pcaBS1_1888R & & GATTCCTAGCCAAGATCCGG \\
\hline $\mathrm{N}$ terminus HiCMLE2 & pcaB2S1_X_N & & GCTGCCATATGAGTTTCTCTCCTCTTG \\
\hline C terminus HiCMLE2 & pcaB2S1_X_B & & AACGGATCCTTTTAGGCCCGATGG \\
\hline C terminus HiCMLE2 + His-tag & pcaB2S1-X_HisT & & TTTTGGATCCGGCCCGATGGTTAAGGGC \\
\hline $\begin{array}{l}\text { C terminus of CMLE from } \\
\text { P. putida PRS2000 }\end{array}$ & pPcaB-X-C2 & & AAAAGGATCCTCACCCAGCACCGCACGCAGG \\
\hline
\end{tabular}

${ }^{\star}$ The underlined sequences indicate the recognition sites for the restriction endonucleases NdeI and BamHI.

$\dagger$ The oligonucleotides were deduced from the consensus sequences of different CMLEs. The amino acid sequences corresponded to aa 37-45 and 280-288 of ArCMLE2. 
Partial inverse PCR. For the determination of the complete sequence of pcaB2S1 from $H$. intermedia S1, a partial inverse PCR was performed (Pang \& Knecht, 1997). The template was prepared by digesting chromosomal DNA (200 ng) of strain S1 for $1 \mathrm{~h}$ at $37^{\circ} \mathrm{C}$ with PauI and religating the fragments obtained with T4 DNA ligase. The primers for this PCR (pcaBS1_1930F and pcaBS1_1888R; Table 2) were deduced from the fragment of pcaB2S1 obtained previously. The following PCR program was used: an initial denaturation $\left(95^{\circ} \mathrm{C}, 1 \mathrm{~min}\right)$ was followed by 30 cycles consisting of an annealing step $\left(60^{\circ} \mathrm{C}, 1 \mathrm{~min}\right)$, a polymerization step $\left(72^{\circ} \mathrm{C}, 4 \mathrm{~min}\right)$ and a denaturation step $\left(95^{\circ} \mathrm{C}, 1 \mathrm{~min}\right)$. This resulted in the amplification of an approximately $2.4 \mathrm{~kb}$ fragment.

\section{Construction of expression plasmids for the production of the CMLEs from A. radiobacter S2 (ArCMLE2), $H$. intermedia S1 (HiCMLE2) and $P$. putida PRS2000 (PpCMLE1) in E. coli. The genes pcaB2S1, pcaB2S2 and $p c a B$ encoding HiCMLE2, ArCMLE2 and PpCMLE1, respectively, were amplified by PCR. The primers used simultaneously introduced NdeI sites upstream and BamHI sites downstream of the genes (see Table 2). The PCR pro- ducts were then cleaved with $\mathrm{NdeI}$ and $\mathrm{BamHI}$ and inserted into NdeI/BamHI-cut expression vectors, resulting in amino-terminally His-tagged enzyme variants.}

The pcaB2S2 gene from A. radiobacter $\mathrm{S} 2$ was amplified by PCR using the oligonucleotide primers CMLEII-X-N and CMLEII-X-C. The following PCR program was used: an initial denaturation $\left(94^{\circ} \mathrm{C}\right.$, $1 \mathrm{~min})$ was followed by 30 cycles consisting of an annealing step $\left(65^{\circ} \mathrm{C}\right.$, $1 \mathrm{~min})$, a polymerization step $\left(72^{\circ} \mathrm{C}, 2 \mathrm{~min}\right)$ and a denaturation step $\left(94^{\circ} \mathrm{C}, 1 \mathrm{~min}\right)$. The amplified and digested DNA fragment was subsequently cloned into the expression vector pAC28 (Kholod \& Mustelin, 2001).

HiCMLE2 was amplified using $P f u$ DNA polymerase (Stratagene) from the genomic DNA of $H$. intermedia S1 using primers pcaB2S1_X_N and pcaB2S1_X_B (Table 2), which were derived from the DNA sequence of the $2.4 \mathrm{~kb}$ DNA fragment obtained by inverse PCR (see above). The following PCR program was used: an initial denaturation $\left(96^{\circ} \mathrm{C}, 2 \mathrm{~min}\right)$ was followed by 30 cycles consisting of an annealing step $\left(63.5^{\circ} \mathrm{C}, 1 \mathrm{~min}\right)$, a polymerization step $\left(72{ }^{\circ} \mathrm{C}, 2 \mathrm{~min}\right)$ and a denaturation step $\left(96^{\circ} \mathrm{C}, 30 \mathrm{~s}\right)$. The amplified product was cleaved with NdeI and BamHI and ligated into pJOE3075 (Stumpp et al., 2000). Finally, E. coli JM 109 was transformed with the resulting plasmid pSBCMC2S1. A variant of the enzyme with an amino-terminal His-tag was constructed by cutting out pcaB2S1 from pSBCMC2S1 using NdeI and $\mathrm{BamHI}$ and cloning it into the expression vector pAC28, giving plasmid pSHCMC2S1.

The $p c a B$ gene was amplified using primers $\mathrm{pPcaB}-\mathrm{X}-\mathrm{N} 2$ and $\mathrm{pPcaB}-\mathrm{X}$ C2 (Table 2), which were deduced from the known nucleotide sequence of the gene [National Center for Biotechnology Information (NCBI) no. L17082]. The following PCR program was used: an initial denaturation $\left(94^{\circ} \mathrm{C}, 2 \mathrm{~min}\right)$ was followed by 30 cycles consisting of an annealing step $\left(65^{\circ} \mathrm{C}, 30 \mathrm{~s}\right)$, a polymerization step $\left(72^{\circ} \mathrm{C}, 1 \mathrm{~min}\right)$ and a denaturation step $\left(94^{\circ} \mathrm{C}, 30 \mathrm{~s}\right)$. The amplified product was cleaved with NdeI and BamHI and cloned into pAC28, giving PSHPpCMLE.

Expression of HiCMLE2, ArCMLE2 and PpCMLE1 in E. coli. The three CMLEs were heterologously produced as amino-terminally His-tagged enzyme variants using E. coli BL21(DE3)(pLysS) Star(pSHCMC2S2) for ArCMLE2, E. coli BL21(DE3)(pLysS) Star(pSHCMC2S1) for HiCMLE2 and E. coli BL21(DE3)(pLysS) Star(pSHPpCMLE) for PpCMLE. The strains were grown in $300 \mathrm{ml}$ LB medium (plus $50 \mu \mathrm{g}$ kanamycin $\mathrm{ml}^{-1}$ ) and the expression of the CMLEs was induced with $1 \mathrm{mM}$ IPTG. The cells were harvested by centrifugation, resuspended in Tris/ $\mathrm{HCl}$ buffer $(50 \mathrm{mM}, \mathrm{pH} 8 \cdot 0)$, disintegrated using a French Press, and cell extracts were prepared by centrifugation at $100000 \mathrm{~g}$ for $30 \mathrm{~min}$ at $4{ }^{\circ} \mathrm{C}$. The CMLEs were purified using an Ni-NTA-column (25 ml; Qiagen) attached to an FPLC-apparatus (Pharmacia). The column was equilibrated with Tris/ $\mathrm{HCl}(50 \mathrm{mM}, \mathrm{pH} 8 \cdot 0), \mathrm{NaCl}(300 \mathrm{mM})$, imidazole $(20 \mathrm{mM})$ and DTT $(1 \mathrm{mM})$. The CMLEs were eluted from the column by increasing the imidazole concentration to $200 \mathrm{mM}$ in the buffer system described above. Fractions $(5 \mathrm{ml}$ each) were collected, the fractions with the CMLEs (usually fractions 3-5) were pooled and the elution buffer was removed using an ultrafiltration unit $(20 \mathrm{ml}$ Concentrator, 100000 molecular mass cut-off; Vivascience). Finally, the concentrated enzyme solution was diluted with $\mathrm{Tris} / \mathrm{HCl}$ $(50 \mathrm{mM}, \mathrm{pH} 8 \cdot 0)$. This procedure resulted in enzyme preparations of HiCMLE2 and ArCMLE2 which appeared on silver-stained gels to be greater than $99 \%$ pure for both enzymes.

Nucleotide sequence analysis. The DNA sequences were determined by dideoxy-chain termination with double-stranded DNA of overlapping subclones in an automated DNA sequencing system (ALF-Sequencer; Amersham-Pharmacia) with fluorescently labelled primers.

Sequence analysis, database searches and comparisons were done with the Lasergene software package, version 5 (DNASTAR) and the BLAST search facility at NCBI (Altschul et al., 1997). The alignments of the CMLEs were obtained with the program CLUSTALX using default parameters.

Estimation of protein concentration and enzyme assays. The protein content of cell-free extracts was determined by the method of Bradford (1976). Bovine serum albumin was used as standard. One unit of enzyme activity was defined as the amount of enzyme that converts $1 \mu \mathrm{mol}$ substrate $\min ^{-1}$.

CMLE activity was measured using the spectrophotometric assay described by Ornston \& Stanier (1966). The assays contained $100 \mu \mathrm{M}$ 3-carboxy-cis,cis-muconate (synthesized enzymically from protocatechuate, see below) and $50 \mathrm{mM}$ Tris/ $\mathrm{HCl}$ buffer $(\mathrm{pH} 8 \cdot 0)$ in a final volume of $1 \mathrm{ml}$. The decrease of absorption was determined at $260 \mathrm{~nm}$. The reaction rates were calculated by using a molar extinction coefficient of $\varepsilon_{260}=7 \cdot 3 \mathrm{mM}^{-1} \mathrm{~cm}^{-1}$.

The turnover of 3-sulfomuconate was analysed by HPLC. The reaction mixtures contained $50 \mathrm{mM}$ Tris/ $\mathrm{HCl}$ buffer $(\mathrm{pH} \mathrm{8.0)}$ and $100 \mu \mathrm{M} 3$ sulfomuconate (synthesized enzymically from 4-sulfocatechol; see below). The reactions were usually monitored for $14 \mathrm{~min}$, every $2 \mathrm{~min}$ aliquots ( $60 \mu \mathrm{l}$ each) were removed, and the reactions were terminated in liquid nitrogen. The samples were separately thawed immediately before the HPLC analysis and the reaction rates were calculated from the time-dependent decrease in 3-sulfomuconate concentration.

Determination of molecular mass. The relative molecular masses of the native enzymes were determined by gel filtration using a Superdex 200 prep grade column (Amersham Biosciences) calibrated with an HMW Gel Filtration Calibration Kit (Amersham Biosciences). The subunit sizes were determined by SDS-PAGE with a Premixed Protein Molecular Mass Marker 14·4-97·4 kDa Kit (Roche) as reference proteins.

SDS-PAGE. SDS-PAGE was performed by the method of Laemmli (1970) and the gels were routinely stained with Coomassie blue. In some experiments the gels were silver-stained using a Dodeca Silver Stain Kit (Bio-Rad).

HPLC. The turnover of 4-sulfocatechol and 3-sulfomuconate was analysed by reversed-phase HPLC (pump model 510 equipped with a photodiode array detector, model 996, and Millenium Chromatography Manager 2.0; Waters Associates). A reversed-phase column $(250 \times 4.0 \mathrm{~mm}$ i.d., packed with $3 \mu \mathrm{m}$ particles of Nucleosil C18) was used. The mean flow rate was $1 \mathrm{ml} \mathrm{min}^{-1}$. The separated compounds were detected photometrically at $210 \mathrm{~nm}$ 
using a photodiode array detector. The solvent system consisted of $98.9 \%(\mathrm{v} / \mathrm{v})$ water, $1 \%(\mathrm{v} / \mathrm{v})$ methanol and $0 \cdot 1 \%(\mathrm{v} / \mathrm{v}) \mathrm{H}_{3} \mathrm{PO}_{4}$. The mean retention times of 4-sulfocatechol, 3-sulfomuconate and 4-sulfomuconolactone under these chromatographic conditions were $3 \cdot 7$, $3 \cdot 4$ and $4 \cdot 3 \mathrm{~min}$, respectively.

Liquid chromatography (LC)-MS. Products were identified by using LC-MS (HP1100; Agilent) coupled to a triple quadrupole mass spectrometer (Quattro LC; Micromass) using electrospray ionization in the negative ion mode. Substrate solutions before and immediately after addition of enzyme and $20 \mathrm{~min}$ after addition of the enzyme were injected $(20 \mu \mathrm{l})$ into the HPLC system without any pretreatment. Analytes were separated by ion-pair chromatography on a Luna C18(2) $3 \mu \mathrm{m}$ column, $15 \mathrm{~cm} \times 3 \mathrm{~mm}$ i.d. at $40^{\circ} \mathrm{C}$. Eluent A was $\mathrm{H}_{2} \mathrm{O} / \mathrm{MeOH}\left(80: 20\right.$, v/v) and eluent $\mathrm{B}, \mathrm{H}_{2} \mathrm{O} / \mathrm{MeOH}(5: 95 \mathrm{v} / \mathrm{v})$ with $5 \mathrm{mM}$ tributylamine and $5 \mathrm{mM}$ acetic acid. The gradient was $22 \%(\mathrm{v} / \mathrm{v}) \mathrm{B}$ at $0 \mathrm{~min}, 22 \% \mathrm{~B}$ at $2 \mathrm{~min}, 90 \% \mathrm{~B}$ at $10 \mathrm{~min}, 90 \% \mathrm{~B}$ at $14 \mathrm{~min}$ and $22 \% \mathrm{~B}$ at $15 \mathrm{~min}$, ready for injection after $22 \mathrm{~min}$. A diode array detector and the mass spectrometer were coupled in series. The mass spectrometric interface was operated at a cone voltage of $18 \mathrm{~V}$ and a capillary voltage of $2.9 \mathrm{kV}$. The probe temperature was $220^{\circ} \mathrm{C}$ and the source block temperature $120^{\circ} \mathrm{C}$. Product ion spectra were recorded at collision energies of $10 \mathrm{eV}$ and $15 \mathrm{eV}$ with a scan rate of $0.5 \mathrm{~s}$.

Preparation of 3-carboxy-cis,cis-muconate and 3-sulfomuconate. The substituted muconates were prepared enzymically using protocatechuate dioxygenase activity (type 2), according to a method described by Ornston \& Stanier (1966) for the preparation of 3-carboxy-cis,cis-muconate. The source of the required dioxygenase activity was E. coli BL21(DE3)(pLysS)(pETS2-X-II), which heterologously expresses P34OII from A. radiobacter S2 under the control of a phage T7 promoter (Contzen \& Stolz, 2000). The strain was grown in $300 \mathrm{ml} \mathrm{LB}$ medium (plus $100 \mu \mathrm{g}$ ampicillin $\mathrm{ml}^{-1}$ ) and the expression of P34OII was induced with IPTG $(0.4 \mathrm{mM})$. The cells were harvested by centrifugation, resuspended in Tris/ $\mathrm{HCl}$ buffer $(50 \mathrm{mM}, \mathrm{pH} 8 \cdot 0)$, disintegrated and cell extracts prepared. The cell extracts (about $2 \mathrm{ml}$ with a protein content of about $40 \mathrm{mg} \mathrm{ml}^{-1}$ ) were mixed with $10 \mathrm{ml}$ Tris/ $\mathrm{HCl}(50 \mathrm{mM}, \mathrm{pH} 8 \cdot 0)$ and protocatechuate or 4 -sulfocatechol was added (4 mM each). The reaction mixtures were incubated at $30{ }^{\circ} \mathrm{C}$ on a laboratory shaker (100 r.p.m.).

The cell-free extract incubated with 4-sulfocatechol was analysed simultaneously by overlay spectra and HPLC analysis. The overlay spectra demonstrated the characteristic decrease in absorbance at $280 \mathrm{~nm}$ due to the turnover of 4-sulfocatechol (Hammer et al., 1996). HPLC analysis with a reverse phase column [solvent system $98.9 \%$ $(\mathrm{v} / \mathrm{v})$ water, $1 \%(\mathrm{v} / \mathrm{v})$ methanol, $0 \cdot 1 \%(\mathrm{v} / \mathrm{v}) \mathrm{H}_{3} \mathrm{PO}_{4}$ ] indicated that $4-$ sulfocatechol $\left(R_{\mathrm{t}}=3.7 \mathrm{~min}\right.$; in situ-recorded $\left.\lambda_{\max }=232 \mathrm{~nm}, 281 \mathrm{~nm}\right)$ was converted to a new metabolite $\left(R_{\mathrm{t}}=3.5 \mathrm{~min} ; \lambda_{\max }=205 \mathrm{~nm}\right)$. The turnover of 4-sulfocatechol to 3-sulfomuconate was additionally verified by HPLC-MS/MS analysis. A new signal occurred $\left(R_{\mathrm{t}}=9.9 \mathrm{~min}\right)$ with a molecular anion mass $[\mathrm{M}-\mathrm{H}]^{-}$of $\mathrm{m} / z 221$ that corresponds to sulfomuconate $\left(\mathrm{C}_{6} \mathrm{H}_{6} \mathrm{O}_{7} \mathrm{~S}\right)$. Fragment ions detected in product ion spectra indicated the presence of one sulfonate moiety and two carboxylate groups: $\mathrm{m} / z 177$ (M-H-CO $\left.{ }_{2}\right), 149$ (177-CO), 139 (M$\left.\mathrm{H}-\mathrm{H}_{2} \mathrm{SO}_{3}\right), 113\left(177-\mathrm{CO}_{2}\right), 95\left(139-\mathrm{CO}_{2}\right)$ and $81\left(\mathrm{HSO}_{3}^{-}\right)$.

The solutions of the substituted muconates were separated from the proteins by ultrafiltration (30000 molecular mass cut-off; Vivaspin). The resulting filtrate containing 3-carboxy- or 3-sulfomuconate was used for the enzymic tests.

Chemicals. The chemicals used were obtained from Aldrich, Fluka, Merck and Sigma. 4-Sulfocatechol was synthesized according to the procedure described by Quilico (1927).

\section{RESULTS}

\section{Identification, cloning and sequencing of the gene encoding the CMLE (type 2 enzyme) from A. radiobacter S2 (ArCMLE2)}

The genes encoding P34OII from A. radiobacter S2 were previously cloned in the recombinant plasmid pMCS2-2 together with two ORFs which showed the highest degree of sequence similarity to a transport system for C4-carboxylates (TRAP-transporter). Approximately 3100 bp downstream of $p c a G 2$, a third ORF was identified which showed sequence similarities to a putative regulator of the IclR family, and further downstream a part of a gene with sequence similarities to $p c a B s$ was detected (Contzen \& Stolz, 2000). In the course of the present study, the DNA insert on pMCS2-2 was completely sequenced and it was found that this gene, designated pcaB2S2, encodes ArCMLE2, a protein of 407 aa with $37-42 \%$ sequence identity to previously described CMLEs (Fig. 2).

\section{Identification and cloning of the gene encoding HiCMLE2 from $\boldsymbol{H}$. intermedia $\mathrm{S1}$}

The genes encoding the P34OII from $H$. intermedia S1 have already been cloned (Contzen et al., 2001). Various attempts to obtain DNA fragments adjacent to pcaH2G2 by partial inverse PCR only resulted in the cloning of a $1180 \mathrm{bp}$ fragment which contained a putative transposase gene about $270 \mathrm{bp}$ downstream of pcaH2G2. Therefore, sequence alignments were performed using the gene sequence obtained from strain S2 (see above) and those of the CMLEs from Streptomyces sp. strain 2065 (NCBI no. AAD40814), Streptomyces coelicolor (T35016), Pseudomonas aeruginosa PAO1 (NP_248921), P. putida (P32427), Bradyrhizobium japonicum USDA110 (O31385), Acinetobacter sp. ADP1 (Q59092) and Agrobacterium tumefaciens C58 (AAK88905). These alignments demonstrated the presence of two highly conserved regions among all sequences, and the sequences (encoding aa $37-45$ and 280-288 in ArCMLE2) were used to design PCR primers (Table 2). A PCR using these primers and genomic DNA from strain S1 resulted in the amplification of a DNA fragment with the expected size (about $750 \mathrm{bp}$ ). The fragment was sequenced and shown to encode part of a putative CMLE. Because in A. radiobacter S2 pcaH2G2 and pcaB2S2 are physically connected, another PCR experiment was performed with genomic DNA from strain $H$. intermedia S1 using one of the primers deduced from the conserved regions in the CMLEs (c-S1-as/a; Table 2) and another one (S1-pcaG/se; Table 2) from the region downstream of pcaG2 known from previous work. This PCR resulted in the amplification of an approximately $2 \mathrm{~kb}$ DNA fragment. Sequencing of this fragment demonstrated that the putative pcaB2S1 was situated downstream of the putative transposase which, in turn, was located downstream of pcaH2G2. The missing part of pcaB2S1 was finally obtained using partial inverse PCR (see Methods). The gene encoded HiCMLE2, a protein of 453 aa (HiCMLE2) with 




Fig. 2. Sequence alignment of different CMLEs. Residues that are identical in all sequences are highlighted by black boxes. The accession numbers and references for the published sequences of the enzymes from P. putida, Acinetobacter sp. ADP1 and Agrobacterium tumefaciens C58 are P32427 (Williams et al., 1992), Q59092 (Kowalchuk et al., 1994), and AAK88905 (Wood et al., 2001), respectively. significant homology to known CMLEs over its complete length (Fig. 2).

\section{Comparison of the amino acid sequences of ArCMLE2 and HiCMLE2 with other CMLEs from different bacteria}

A comparison of the deduced amino acid sequences of HiCMLE2 and ArCMLE2 and the sequences of other proven or putative CMLEs from the NCBI database clearly demonstrated that the two type 2 enzymes were more closely related to each other than to the other CMLEs (Fig. 3). The two presumed type 2 enzymes showed $50 \%$ sequence identity, which was significantly higher than the sequence identities of 33-43\% observed between the two type 2 enzymes and all other previously described CMLEs (including all sequences of presumed CMLEs from various genome sequencing projects).

\section{Comparison of the organization of the type 2 gene clusters to the protocatechuate gene clusters from different bacteria}

The genes encoding the P34OIIs and CMLE2s were organized in $H$. intermedia S1 and A. radiobacter S2 in a different way to all known variations in the structures of protocatechuate operons. Moreover, in strains S1 and S2 the genes encoding the P34OIIs and the CMLE2s were separated by different genes (Fig. 4). This indicates that no strictly conserved 4-sulfocatechol degradation operon exists and that the two pathways were not established in both strains by recent gene exchange events.

\section{Expression of ArCMLE2 and HiCMLE2}

The genes encoding HiCMLE2 and ArCMLE2 were cloned into the expression plasmid pAC28 under the control of the phage T7 promoter system (Kholod \& Mustelin, 2001), giving plasmids $\mathrm{pSHCMC2S1}$ and $\mathrm{pSHCMC2S2}$, respectively. This resulted in the formation of carboxy- and amino-terminally His-tagged proteins. The expression of the genes by the addition of IPTG resulted in the formation of additional peptides in the crude extracts. The sizes of the additional bands were estimated by SDS-PAGE for both HiCMLE2 and ArCMLE2 at approximately $42 \mathrm{kDa}$. The CMLE activities of the recombinant E. coli strains were tested using the spectrophotometric enzyme assay described by Ornston \& Stanier (1966). Thus it was shown that the cell extracts from E. coli BL21(DE3)(pLysS)(pSHCMC2S1) and E. coli BL21(DE3)(pLysS)(pSHCMC2S2) converted 3carboxy-cis,cis-muconate with specific activities of 0.67 and $0.5 \mathrm{U}$ (mg protein $)^{-1}$, respectively.

\section{Turnover of 3-sulfomuconate by HiCMLE2 and ArCMLE2}

Cell extracts were prepared from E. coli BL21(DE3)(pLysS) Star carrying plasmids pSHCMC2S1 or pSHCMC2S2 and incubated with 3 -sulfomuconate (1-4 mM). These reactions were analysed by HPLC because 3-sulfomuconate, unlike most other substituted muconates, does not have pronounced 


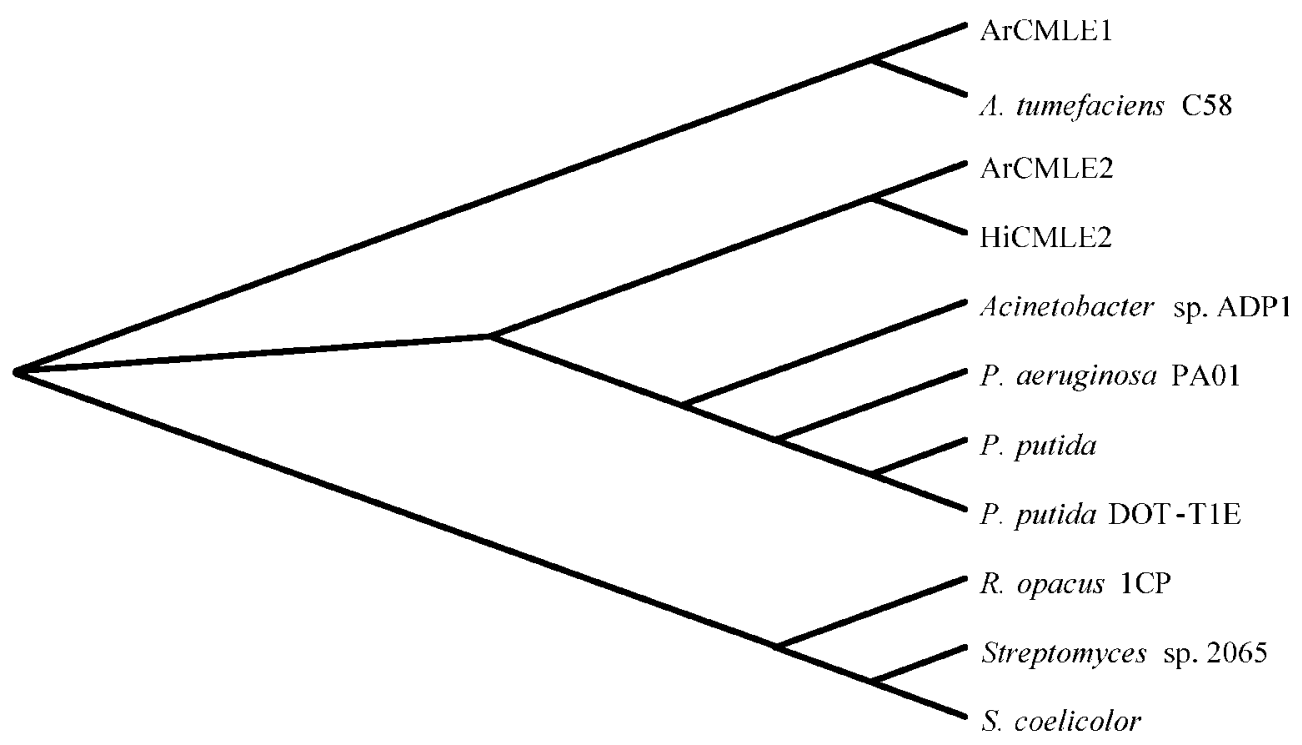

Fig. 3. Dendrogram showing the phylogenetic relatedness of CMLEs from different bacterial sources. The dendrogram was produced using the programs CLUSTALX and TREEVIEW (Page, 1996). The references for the sequences from P. putida, Acinetobacter calcoaceticus and Agrobacterium tumefaciens are given in the legend to Fig. 2. The accession numbers and references for the sequences from $B$. japonicum, Rhodococcus opacus $1 \mathrm{CP}, P$. putida DOT-T1E, $P$. aeruginosa, Streptomyces sp. 2065 and S. coelicolor are O31385 (Lorite et al., 1998), AAC38245 (Eulberg et al., 1998), AAD39559 (Ramos et al., 1998), NP_248921 (Stover et al., 2000), AAD40814 (Iwagami et al., 2000) and T35016, respectively.

absorbance at $260 \mathrm{~nm}$ (Feigel \& Knackmuss, 1993). HPLC analysis with a reverse phase column (using the same solvent system as above) demonstrated that 3-sulfomuconate $\left(R_{\mathrm{t}}=3.5 \mathrm{~min} ; \lambda_{\max }=205 \mathrm{~nm}\right)$ was converted to a new metabolite $\left(R_{\mathrm{t}}=4 \cdot 2 \mathrm{~min} ; \lambda_{\max }=215 \mathrm{~nm}\right)$. The subsequent analysis of the reaction by HPLC-MS/MS confirmed the turnover of 3-sulfomuconate to 4-carboxymethylene-4-sulfobut-2-en-olide (4-sulfomuconolactone). A new signal was detected $\left(R_{\mathrm{t}}=9 \cdot 0 \mathrm{~min}\right)$ with an $\mathrm{m} / z$ of 221 for the molecular anion $[\mathrm{M}-\mathrm{H}]^{-}$. Less fragmentation occurred than for sulfomuconate, as the cyclic lactone system remained intact and only the exocyclic functional groups were split off as fragments: $177\left(\mathrm{M}-\mathrm{H}-\mathrm{CO}_{2}\right), 139\left(\mathrm{M}-\mathrm{H}-\mathrm{H}_{2} \mathrm{SO}_{3}\right), 95$ (139$\left.\mathrm{CO}_{2}\right)$ and $81\left(\mathrm{HSO}_{3}^{-}\right)$. No reactions were observed in control experiments without added cell extracts or with cell extracts from E. coli which did not express the recombinant enzymes.

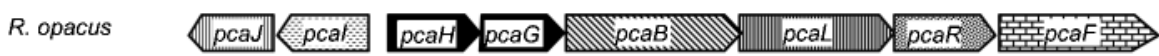 \\ Ac. calcoaceticus pcaU 0 pcal pcaJ



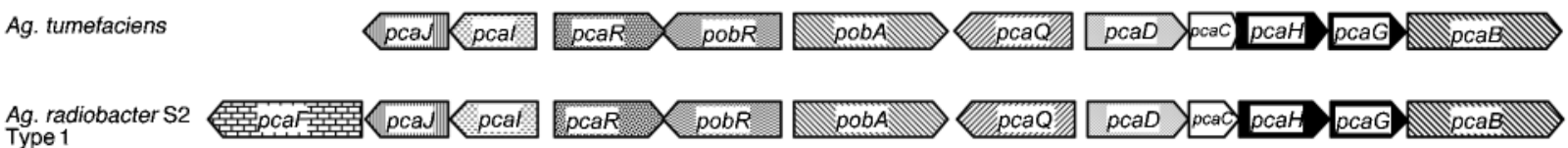

Fig. 4. Structures of gene clusters for the catabolism of protocatechuate and 4-sulfocatechol from $H$. intermedia $\mathrm{S} 1$ and $A$. radiobacter $\mathrm{S} 2$ in comparison to the protocatechuate gene clusters from $R$. opacus, Acinetobacter calcoaceticus, $P$. putida and Agrobacterium tumefaciens (Eulberg et al., 1998; Parke, 1995). 
The recombinant CMLEs were purified by affinity chromatography using their His-tags. The purified enzymes showed (determined with 3-carboxy-cis,cis-muconate as substrate) $\mathrm{pH}$ optima in Tris/ $\mathrm{HCl}$ buffer at $\mathrm{pH} 8.0$ and about $50 \%$ of their maximal activity in Tris/ $\mathrm{HCl}, \mathrm{pH} 9 \cdot 0$, or histidine/ $\mathrm{HCl}, \mathrm{pH} 5 \cdot 8$. The enzymes showed significantly reduced activities in sodium/potassium phosphate/citrate buffers compared to histidine/ $\mathrm{HCl}$ buffers at the same $\mathrm{pH}$, as found previously for the CMLE from P. putida (Ornston, 1966).

In the spectrophotometric tests with 3-carboxy-cis,cismuconate, $v_{\max }$ values of 1.5 and $1.3 \mathrm{U}(\mathrm{mg} \text { protein })^{-1}$ were determined for HiCMLE2 and ArCMLE2, respectively (Table 3 ). These values were significantly lower than those described for the CMLE from $P$. putida [547 U (mg protein $)^{-1}$ ] (Ornston, 1966). Furthermore, HiCMLE2 and ArCMLE2 also showed slightly higher $K_{\mathrm{m}}$ values for 3carboxy-cis,cis-muconate than the enzyme from P. putida (Table 3).

Finally, different concentrations $(0 \cdot 5-4 \mathrm{mM})$ of 3-sulfomuconate were incubated with the purified enzymes, five aliquots of each were taken after different time intervals (2-10 $\mathrm{min})$ and the turnover of 3-sulfomuconate was analysed by HPLC. These experiments suggested that both enzymes showed higher $v_{\max }$ values and lower $K_{\mathrm{m}}$ values with the sulfonated substrate compared to the carboxylated muconate (Table 3 ).

\section{Turnover of 3-sulfomuconate by PpCMLE from P. putida PRS2000}

We tested if also the 'archetypal' CMLE from the protocatechuate pathway of $P$. putida PRS2000(PpCMLE1) could convert 3-sulfomuconate. Cell extracts were prepared from cells of $P$. putida PRS2000 grown with protocatechuate (to induce the formation of PpCMLE1). The cell extracts converted 3-carboxy-cis,cis-muconate and surprisingly also 3 -sulfomuconate with specific activities of 2.0 and $0.13 \mathrm{U}$ $(\mathrm{mg} \text { protein })^{-1}$, respectively. To confirm the ability of PpCMLE1 to convert 3-sulfomuconate, the gene was amplified from the chromosomal DNA of P. putida
PRS2000 and cloned into the expression vector pAC28 (see Methods). The enzyme was expressed as a His-tagged enzyme variant and partially purified on an Ni-NTA column to a specific activity of $240 \mathrm{U} \mathrm{mg}^{-1}$ with 3-carboxy-cis,cismuconate as substrate [compared to a $v_{\max }$ reported for the purified enzyme of $457 \mathrm{U}$ (mg protein $)^{-1}$ by Ornston (1966)]. The same enzyme preparation was incubated with 3sulfomuconate $(0 \cdot 5,1,2$ and $3 \mathrm{mM})$ in the HPLC assay used for the CMLEs. Thus it was found that PpCMLE indeed converted 3-sulfomuconate. In these tests the highest reaction rates were observed with $0.5 \mathrm{mM} \mathrm{3-}$ sulfomuconate $\left[8.5 \mathrm{U}(\mathrm{mg} \text { protein })^{-1}\right]$ and a pronounced decrease in the reaction rates was observed using higher substrate concentrations.

\section{DISCUSSION}

The results of the present study and our previous investigations of the 4-sulfocatechol-oxidizing P34OII demonstrated that the degradation of 4-sulfocatechol to 4-sulfomuconolactone is catalysed by two enzymes which are clearly derived from the protocatechuate branch of the $\beta$-ketoadipate pathway. This became evident from the range of substrates converted by both groups of enzymes and the sequence data obtained. It was found previously that the P34OIIs from $H$. intermedia S1 and A. radiobacter S2 converted 4-sulfocatechol and protocatechuate (Contzen et al., 2001). In accordance with this observation, the present study demonstrated that ArCMLE2 and HiCMLE2 converted carboxylated and sulfonated muconates. Furthermore, it was previously shown by multiple sequence alignments that both subunits of the P34OIIs from strains S1 and S2 clustered together with the corresponding subunits of the protocatechuate 3,4-dioxygenases from various protocatechuate-degrading organisms (Contzen \& Stolz, 2000; Contzen et al., 2001) and here we show that the two type 2 CMLEs are also homologues of the CMLEs from protocatechuate-degrading organisms.

The sequence comparisons demonstrated that the two 3sulfomuconate-converting CMLEs investigated in this study

Table 3. Kinetic data for the turnover of 3-carboxy-cis,cis-muconate and 3-sulfomuconate by the 3-carboxy-cis,cis-muconate cycloisomerases from $H$. intermedia $\mathrm{S} 1$ and $A$. radiobacter $\mathrm{S} 2$

MM, molecular mass; 3 CM, 3-carboxy-cis,cis-muconate; 3SM, 3-sulfomuconate. The data were calculated by non-linear regression using Prism 4 software (GraphPad Software).

\begin{tabular}{|c|c|c|c|c|c|c|c|c|}
\hline Enzyme & Source & $\begin{array}{c}\text { MM per } \\
\text { subunit }(\mathrm{kDa})\end{array}$ & Substrate & $\begin{array}{l}K_{\mathrm{m}} \\
(\mathrm{mM})\end{array}$ & $\begin{array}{c}v_{\max } \\
\left(\mathrm{U} \mathrm{mg}^{-1}\right)\end{array}$ & $\begin{array}{c}\boldsymbol{k}_{\mathrm{cat}} \\
\left(\min ^{-1}\right)\end{array}$ & $\begin{array}{c}k_{\mathrm{cat}} / K_{\mathrm{m}} \\
\left(\mathrm{mM}^{-1} \mathrm{~min}^{-1}\right)\end{array}$ & $\begin{array}{c}k_{\mathrm{cat}} / K_{\mathrm{m}} \\
3 \mathrm{SM}: 3 \mathrm{CM}\end{array}$ \\
\hline \multirow[t]{2}{*}{ HiCMLE2 } & H. intermedia S1 & $48 \cdot 4$ & $3 \mathrm{CM}$ & $0 \cdot 15 \pm 0 \cdot 04$ & $1 \cdot 5 \pm 0 \cdot 31$ & 73 & 486 & $0 \cdot 74$ \\
\hline & & & $3 \mathrm{SM}$ & $7 \cdot 1 \pm 1 \cdot 9$ & $53 \pm 10$ & 2565 & 362 & \\
\hline \multirow[t]{2}{*}{ ArCMLE2 } & A. radiobacter $\mathrm{S} 2$ & $42 \cdot 5$ & $3 \mathrm{CM}$ & $0 \cdot 15 \pm 0 \cdot 07$ & $1 \cdot 3 \pm 0 \cdot 4$ & 55 & 368 & $0 \cdot 22$ \\
\hline & & & $3 \mathrm{SM}$ & $15 \cdot 3 \pm 5 \cdot 7$ & $29 \cdot 5 \pm 9 \cdot 2$ & 1254 & 82 & \\
\hline PpCMLE1* & P. putida & $42 \cdot 4$ & $3 \mathrm{CM}$ & $0 \cdot 075$ & 547 & 23200 & 309200 & \\
\hline
\end{tabular}

${ }^{*}$ Data taken from Ornston (1966). 
are more closely related to each other than to the corresponding enzymes from the protocatechuate pathways of various other bacteria. This was especially evident for ArCMLE2 from A. radiobacter S2 which is more closely related to the isofunctional HiCMLE2 from the taxonomically distantly related Hydrogenophaga strain (these organisms belong to the Alpha- or Betaproteobacteria) than to the previously described CMLEs from the protocatechuate pathways of other agrobacteria (Parke, 1996; Wood et al., 2001). This clearly suggested a horizontal transfer of the gene encoding ArCMLE2 from a different genetic background to strain $\mathrm{S} 2$.

Unfortunately, only very limited information is available about the enzymic characteristics of bacterial CMLEs. This is mainly due to the commercial unavailability and instability of the enzyme substrate 3-carboxy-cis,cis-muconate. Thus, since the pioneering work of Ornston (1966), who described the first purification and characterization of a CMLE (from P. putida), no other bacterial CMLEs have been studied in any detail with regard to their enzymic characteristics.

It was a surprising observation that PpCMLE1, which belongs to the protocatechuate pathway of $P$. putida, was also able to convert 3-sulfomuconate. This suggested that for CMLEs, no strict separation into type 1 enzymes (which only accept carboxylated substrates) and type 2 enzymes (which convert carboxylated plus sulfonated substrates) can be used as previously suggested for protocatechuatecleaving activities (Feigel \& Knackmuss, 1993). Nevertheless, it is evident that there are huge differences in the specific activities of the different types of CMLEs for the turnover of 3-carboxy-cis,cis-muconate. The comparison of the data given by Ornston (1966) for the CMLE from $P$. putida (and also our own results obtained with the Histagged enzyme variant PpCMLE1) with HiCMLE2 and ArCMLE2, which participate in the degradation of 4sulfocatechol, showed that the CMLE from $P$. putida converted 3-carboxy-cis,cis-muconate with a much higher $v_{\max }$ and a slightly lower $K_{\mathrm{m}}$ than the type 2 enzymes from $H$. intermedia S1 and $A$. radiobacter S2. The CMLE from $P$. putida therefore seems to be much better adapted to the turnover of 3-carboxy-cis,cis-muconate than the type 2 enzymes studied here.

The analysis of the turnover of 3-sulfomuconate by PpCMLE did not allow a reliable calculation of the kinetic constants because of the observed substrate inhibition kinetics and the inherent difficulties of the HPLC test applied. Nevertheless, it became evident that the relative activities of this enzyme with 3-carboxy-cis,cis-muconate in comparison to the turnover of 3-sulfomuconate are much higher than the corresponding values for HiCMLE2 and ArCMLE2. Surprisingly, it appears that the specific activities of the purified PpCMLE with 3-sulfomuconate are higher than those determined for HiCMLE2 and ArCMLE2. This indicates that, for the turnover of 3-sulfomuconate from the point of enzyme specificity and activity, no specifically adapted CMLEs are necessary. To analyse this apparent contradiction more accurately, we are currently studying the turnover of 3-sulfomuconate by other CMLEs originating from the protocatechuate pathways of different bacteria.

\section{ACKNOWLEDGEMENTS}

We thank T. Reemtsma (Fachgebiet Wasserreinhaltung, Technische Universität Berlin, Germany) for his help during the HPLC/MS analysis of the metabolites, and A. Fischedick for some initial experiments. This work was supported by the Deutsche Forschungsgemeinschaft DFG (Project Sto 400/2).

\section{REFERENCES}

Alexander, M. \& Lustigman, B. K. (1966). Effect of chemical structure on microbial degradation of substituted benzenes. J Agric Food Chem 14, 410-413.

Alonso, M. C., Castillo, M. \& Barceló, D. (1999). Solid-phase extraction procedure of polar benzene- and naphthalenesulfonates in industrial effluents followed by unequivocal determination with ionpair chromatography/electrospray-mass spectrometry. Anal Chem 71, 2586-2593.

Alting-Mees, M. A., Sorge, J. A. \& Short, J. M. (1992). pBluescript II: multifunctional cloning and mapping vectors. Methods Enzymol 216, 483-495.

Altschul, S. F., Madden, T. L., Schäffer, A. A., Zhang, J., Zhang, Z., Miller, W. \& Lipman, D. J. (1997). Gapped BLAST and PSI-BLAST: a new generation of protein database search programs. Nucleic Acids Res 25, 3389-3402.

Bradford, M. M. (1976). A rapid and sensitive method for the quantitation of protein utilizing the principle of protein dye binding. Anal Biochem 72, 248-254.

Brilon, C., Beckmann, W. \& Knackmuss, H.-J. (1981). Catabolism of naphthalenesulfonic acids by Pseudomonas sp. A3 and Pseudomonas sp. C22. Appl Environ Microbiol 42, 44-55.

Chung, C. T., Niemela, S. L. \& Miller, R. H. (1989). One-step preparation of competent Escherichia coli: transformation and storage of bacterial cells in the same solution. Proc Natl Acad Sci U S A 86, 2172-2175.

Contzen, M. \& Stolz, A. (2000). Characterization of the genes for two protocatechuate 3,4-dioxygenases from the catechol-4-sulfonate degrading bacterium Agrobacterium radiobacter strain S2. J Bacteriol 182, 6123-6129.

Contzen, M., Wittich, R.-M., Knackmuss, H.-J. \& Stolz, A. (1996). Degradation of benzene-1,3-disulfonate by a mixed bacterial culture. FEMS Microbiol Lett 136, 45-50.

Contzen, M., Moore, E. R. B., Blümel, S., Stolz, A. \& Kämpfer, P. (2000). Hydrogenophaga intermedia sp. nov., a 4-aminobenzenesulfonate degrading organism. Syst Appl Microbiol 23, 487-493.

Contzen, M., Bürger, S. \& Stolz, A. (2001). Cloning of the genes for a 4-sulfocatechol-oxidizing protocatechuate 3,4-dioxygenase from Hydrogenophaga intermedia S1 and identification of the amino acid residues responsible for the ability to convert 4-sulfocatechol. Mol Microbiol 41, 199-205.

Cook, A. M., Laue, H. \& Junker, F. (1999). Microbial desulfonation. FEMS Microbiol Rev 22, 399-419.

Dong, W., Eichhorn, P., Radajewski, S., Schleheck, D., Denger, K., Knepper, T. P., Murrell, J. C. \& Cook, A. M. (2004). Parvibaculum lavamentivorans converts linear alkylbenzenesulfonate surfactant to sulfophenylcarboxylates, $\alpha, \beta$-unsaturated sulfophenylcarboxylates 
and sulfophenyldicarboxylates, which are degraded in communities. J Appl Microbiol 96, 630-640.

Dorn, E., Hellwig, M., Reineke, W. \& Knackmuss, H.-J. (1974). Isolation and characterization of a 3-chlorobenzoate degrading pseudomonad. Arch Microbiol 99, 61-70.

Eulberg, D., Golovleva, L. A. \& Schlömann, M. (1997). Characterization of catechol catabolic genes from Rhodococcus opacus 1CP. J Bacteriol 179, 370-381.

Eulberg, D., Lakner, S., Golovleva, L. A. \& Schlömann, M. (1998). Characterization of a protocatechuate catabolic gene cluster from Rhodococcus opacus 1CP: evidence for a merged enzyme with 4carboxymuconolactone-decarboxylating and 3-oxoadipate enol-lactone-hydrolyzing activity. J Bacteriol 180, 1072-1081.

Feigel, B. J. \& Knackmuss, H.-J. (1988). Bacterial catabolism of sulfanilic acid via catechol-4-sulfonic acid. FEMS Microbiol Lett 55, 113-118.

Feigel, B. J. \& Knackmuss, H.-J. (1993). Syntrophic interactions during degradation of 4-aminobenzenesulfonic acid by a two-species bacterial culture. Arch Microbiol 159, 124-130.

Hammer, A., Stolz, A. \& Knackmuss, H.-J. (1996). Purification and characterization of a novel type of protocatechuate-3,4-dioxygenase with the ability to oxidize 4-sulfocatechol. Arch Microbiol 166, 92-100.

Hughes, E. J., Shapiro, M. K., Houghton, J. E. \& Ornston, L. N. (1988). Cloning and expression of pca genes from Pseudomonas putida in Escherichia coli. J Gen Microbiol 134, 2877-2887.

Iwagami, S. G., Yang, K. \& Davies, J. (2000). Characterization of the protocatechuic acid catabolic gene cluster from Streptomyces sp. strain 2065. Appl Environ Microbiol 66, 1499-1508.

Kholod, N. \& Mustelin, T. (2001). Novel vectors for co-expression of two proteins in E. coli. Biotechniques 31, 322-328.

Knepper, T. P. (2002). Mass spectrometric strategies for the analysis of polar industrial chemicals and their by-products in wastewater and surface water. J Chromatogr A 974, 111-121.

Kowalchuk, G. A., Hartnett, G. B., Benson, A., Houghton, J. E., Ngai, K. L. \& Ornston, L. N. (1994). Contrasting patterns of evolutionary divergence within the Acinetobacter calcoaceticus pca operon. Gene 146, 23-30.

Laemmli, U. K. (1970). Cleavage of structural proteins during the assembly of the head of bacteriophage T4. Nature 227, 680-685.

Lorite, M. J., Sanjuan, J., Velasco, L., Olivares, J. \& Bedmar, E. J. (1998). Characterization of Bradyrhizobium japonicum pcaBDC genes involved in 4-hydroxybenzoate degradation. Biochim Biophys Acta 1397, 257-261.

Marchuk, D., Drumm, M., Saulino, A. \& Collins, F. S. (1991). Construction of T-vectors, a rapid and general system for direct cloning of unmodified PCR products. Nucleic Acids Res 19, 1154.

Nörtemann, B., Baumgarten, J., Rast, H. G. \& Knackmuss, H.-J. (1986). Bacterial communities degrading amino- and hydroxynaphthalene-2-sulfonates. Appl Environ Microbiol 52, 1195-1202.

Ohe, T., Ohmoto, T., Kobayashi, Y., Sato, A. \& Watanabe, Y. (1990). Metabolism of naphthalenesulfonic acids by Pseudomonas sp. TA-2. Agric Biol Chem 54, 669-675.

Ornston, L. N. (1966). The turnover of catechol and protocatechuate to $\beta$-ketoadipate by Pseudomonas putida. II. Enzymes of the protocatechuate pathway. J Biol Chem 241, 3787-3794.

Ornston, L. N. \& Stanier, R. Y. (1966). The turnover of catechol and protocatechuate to $\beta$-ketoadipate by Pseudomonas putida. I. Biochemistry. J Biol Chem 241, 3776-3786.

Page, R. D. M. (1996). TREEVIEW: an application to display phylogenetic trees on personal computers. Comput Appl Biosci 12, 357-358.
Pang, K. M. \& Knecht, D. A. (1997). Partial inverse PCR: a technique for cloning flanking sequences. Biotechniques 22, 1046-1048.

Parke, D. (1995). Supraoperonic clustering of pca genes for catabolism of the phenolic compound protocatechuate in Agrobacterium tumefaciens. J Bacteriol 177, 3808-3817.

Parke, D. (1996). Characterization of $\mathrm{PcaQ}$, a LysR-type transcriptional activator required for catabolism of phenolic compounds from Agrobacterium tumefaciens. J Bacteriol 178, 266-272.

Quilico, A. (1927). Azione dell'acido amminosolfonico sui difenol. Gazz Chim Ital 57, 793-802.

Ramos, J. L., Duque, E., Godoy, P. \& Segura, A. (1998). Efflux pumps involved in toluene tolerance in Pseudomonas putida DOTT1E. J Bacteriol 180, 3323-3329.

Riediker, S., Suter, M. J.-F. \& Giger, W. (2000). Benzene- and naphthalenesulfonates in leachates and plumes of landfills. Water Res 34, 2069-2079.

Ruckstuhl, S., Suter, M. J.-F., Kohler, H.-P. E. \& Giger, W. (2002). Leaching and primary biodegradation of sulfonated naphthalenes and their formaldehyde condensates from concrete superplasticizers in groundwater affected by tunnel construction. Environ Sci Technol 36, 3284-3289.

Sambrook, J., Fritsch, E. F. \& Maniatis, T. (1989). Molecular Cloning: a Laboratory Manual, 2nd edn. Cold Spring Harbor, NY: Cold Spring Harbor Press.

Schleheck, D., Knepper, T. P., Fischer, K. \& Cook, A. M. (2004). Mineralization of individual congeners of linear alkylbenzenesulfonate by defined pairs of heterotrophic bacteria. Appl Environ Microbiol 70, 4053-4063.

Schulz, S., Dong, W., Groth, U. \& Cook, A. M. (2000). Enantiomeric degradation of 2-(4-sulfophenyl)butyrate via 4-sulfocatechol in Delftia acidovorans SPB1. Appl Environ Microbiol 66, 1905-1910.

Stover, C. K., Pham, X.-Q. T., Erwin, A. L. \& 28 other authors (2000). Complete genome sequence of Pseudomonas aeruginosa PA01, an opportunistic pathogen. Nature 406, 959-964.

Stumpp, T., Wilms, B. \& Altenbuchner, J. (2000). Ein neues, LRhamnose-induzierbares Expressionssystem für Escherichia coli. Biospektrum 6, 33-36.

Thurnheer, T., Zürrer, D., Höglinger, O., Leisinger, T. \& Cook, A. M. (1990). Initial steps in the degradation of benzene sulfonic acid, 4toluene sulfonic acids, and orthanilic acid in Alcaligenes sp. strain $\mathrm{O}$ 1. Biodegradation 1, 55-64.

Tully, P. S. (1997). Sulfonic acids. In Kirk-Othmer Encylopedia of Chemical Technology, 4th edn, vol. 23, pp. 194-217. New York: Wiley. Wellens, H. (1990). Zur biologischen Abbaubarkeit mono- und disubstituierter Benzolderivate. Z Wasser Abwasser Forsch 23, 85-98.

Williams, S. E., Woolridge, E. M., Ransom, S. C., Landro, J. A., Babbitt, P. C. \& Kozarich, J. W. (1992). 3-Carboxy-cis,cis-muconate lactonizing enzyme from Pseudomonas putida is homologous to the class II fumarase family. A new reaction in the evolution of a mechanistic motif. Biochemistry 31, 9768-9776.

Wittich, R.-M., Rast, H. G. \& Knackmuss, H.-J. (1988). Degradation of naphthalene-2,6- and naphthalene-1,6-disulfonic acid by a Moraxella sp. Appl Environ Microbiol 54, 842-1847.

Wood, D. W., Setubal, J. C., Kaul, R. \& 47 other authors (2001). The genome of the natural genetic engineer Agrobacterium tumefaciens C58. Science 294, 2317-2323.

Yang, J., Wang, Y., Woolridge, E. M., Arora, V., Petsko, G. A., Kozarich, J. W. \& Ringe, D. (2004). Crystal structure of 3-carboxycis,cis-muconate lactonizing enzyme from Pseudomonas putida, a fumarase class II type cycloisomerase: enzyme evolution in parallel pathways. Biochemistry 43, 10424-10434. 